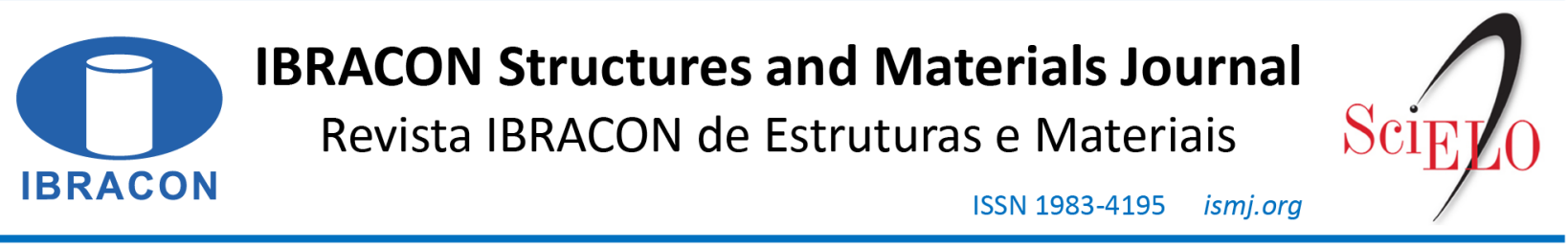

ORIGINAL ARTICLE

\title{
Ultrasonic wave propagation in thermally treated concrete up to 400 으
}

\author{
Propagação de ondas ultrassônicas em concreto termicamente tratado até 400 oc \\ Ana Carolina Costa Viana ${ }^{\mathrm{a}}$ (1) \\ Poliana Dias de Moraes ${ }^{\mathrm{a}}$ (D) \\ Ivo José Padaratz ${ }^{\mathrm{a}}$ (1)

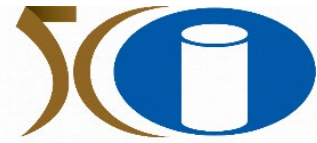 \\ YEARSIBRACON
}

${ }^{a}$ Universidade Federal de Santa Catarina - UFSC, Departmento de Engenharia Civil, Florianópolis, SC, Brasil

Received 06 November 2020

Accepted 21 September 2021

\begin{abstract}
The ultrasonic pulse velocity, obtained by ultrasonic non-destructive testing, has been applied to evaluate the concrete integrity. The attenuation parameters have shown more sensitivity to damage detection in the microstructure of concrete since they consider the entire ultrasonic waveform. However, it is still necessary to evaluate the sensitivity of those parameters to thermally damaged concrete. This work aims to assess the behavior and the sensitivity of the following ultrasonic parameters: pulse and group velocities, maximum amplitude, total energy, accumulated energy, and time instants corresponding to $25 \%, 50 \%$, and $75 \%$ of the energy, in detecting changes due to thermal degradation of the concrete. A sample of 39 cylindrical concrete specimens with $100 \mathrm{~mm}$ in diameter and $300 \mathrm{~mm}$ in length and C25 strength class was used. The sample was distributed into 5 groups heated between 20 and $400{ }^{\circ} \mathrm{C}$ until the internal temperature of the specimens became homogeneous. The groups were cooled inside a muffle furnace until reaching $150{ }^{\circ} \mathrm{C}$. Subsequently, they were exposed to the ambient temperature and humidity of the laboratory environment for, at least, 24 hours prior to the tests of mass loss, ultrasound, and compressive strength. The results show that the ultrasonic parameters are sensitive to the thermal degradation of the concrete. The pulse velocity, the accumulated energy, and the time instants corresponding to percentages of the energy decrease monotonically as the temperature increases. The group velocity shows significant dispersions, while the maximum amplitude and the total energy increase at $200{ }^{\circ} \mathrm{C}$. The results led to the conclusion that the pulse velocity is the least sensitive parameter, while the time instants corresponding to $25 \%, 50 \%$, and $75 \%$ of the energy are the most sensitive parameters in detecting changes due to thermal degradation of the concrete.
\end{abstract}

Keywords: ultrasound, attenuation parameters, sensitivity, concrete, high temperatures.

\begin{abstract}
Resumo: A velocidade de pulso ultrassônico, obtida por meio do ensaio não destrutivo do ultrassom, tem sido usada para avaliar a integridade do concreto. Os parâmetros de atenuação têm apresentado maior sensibilidade na detecção de danos na microestrutura do concreto, visto que consideram todo o formato da onda ultrassônica. Porém, ainda é necessária a avaliação da sensibilidade desses parâmetros ao concreto danificado termicamente. Este trabalho tem como objetivo avaliar o comportamento e a sensibilidade dos seguintes parâmetros ultrassônicos: velocidades de pulso e de grupo, amplitude máxima, energia total, energia acumulada e tempos de propagação correspondentes a $25 \%, 50 \%$ e $75 \%$ da energia, na detecção de mudanças devidas à degradação térmica do concreto. Uma amostra de 39 corpos de prova cilíndricos de concreto de $100 \mathrm{~mm}$ de diâmetro e $300 \mathrm{~mm}$ de comprimento e de classe de resistência $\mathrm{C} 25$ foi usada. Ela foi distribuída em 5 grupos aquecidos entre 20 e $400^{\circ} \mathrm{C}$, até que a temperatura interna dos corpos de prova se tornasse homogênea. Os grupos foram resfriados dentro do forno elétrico até $150^{\circ} \mathrm{C}$. Em seguida, eles foram expostos à temperatura e à umidade do laboratório por, no mínimo, 24 horas antes dos ensaios de perda de massa, de ultrassom e de resistência à compressão. Os resultados mostram que os parâmetros do ultrassom são sensíveis à degradação térmica do concreto. A velocidade de pulso, a energia acumulada e os tempos correspondentes às porcentagens de energia decrescem monotonicamente conforme a temperatura aumenta. A velocidade de grupo apresenta dispersões significativas, enquanto a amplitude máxima e a energia total aumentam aos $200^{\circ} \mathrm{C}$. Os resultados permitem concluir que a velocidade de pulso é o parâmetro que possui menor sensibilidade, enquanto os tempos correspondentes a $25 \%, 50 \%$ e $75 \%$ da energia são considerados os parâmetros de maior sensibilidade na detecção de mudanças devido à degradação térmica do concreto.

Palavras-chave: ultrassom, parâmetros da atenuação, sensibilidade, concreto, altas temperaturas.
\end{abstract}

How to cite: A. C. C. Viana, P. D. Moraes, and I. J. Padaratz, "Ultrasonic wave propagation in thermally treated concrete up to $400{ }^{\circ} \mathrm{C}$," Rev. IBRACON Estrut. Mater., vol. 15, no. 3, e15303, 2022, https://doi.org/10.1590/S1983-41952022000300003

Corresponding author: Ana Carolina Costa Viana. E-mail: anacarolviana@outlook.com

Financial support: Coordination for the Improvement of Higher Education Personnel (CAPES).

Conflict of interest: Not applicable.

Data Availability: The data that support the findings of this study are available from the corresponding author, ACCV, upon reasonable request. 


\section{INTRODUCTION}

Ultrasonic testing is a non-destructive method based on the propagation of stress waves, which has been used in the analysis of concrete quality. It detects superficial and internal damage using a fast and simple procedure. Since it is a non-destructive method, it allows monitoring the internal structure of the concrete. Therefore, ultrasonic testing can help in selecting appropriate procedures for the repair and rehabilitation of concrete structures and in the concrete integrity assessment, even in cases of fire damage [1], [2].

The ultrasonic pulse velocity (UPV) is commonly used to indicate the damage degree, since velocities are generally lower in damaged concrete [3], [4]. However, according to Santhanam [5] and Shiotani and Aggelis [6], this parameter does not give a complete evaluation of the concrete damage since ultrasonic pulse velocity (UPV) is measured from the first detectable wave disturbance. Signal processing applied to the ultrasound method made feasible the analysis of attenuation parameters, such as group velocity, maximum amplitude, and energy, by analyzing the ultrasonic waveforms [7]. Ultrasound attenuation is the result of energy loss due to scattering from the concrete microstructure, which redirects the energy beam, and due to dissipation from the viscoelastic water/cement matrix, which is related to the energy absorption [8].

According to Hauwaert [7], the attenuation parameters are more sensitive to damage since they include information from the ultrasonic signal in an entire time window. Research has shown the sensitivity of attenuation parameters to the presence of cracks and non-homogeneities in concrete specimens with compressive strength of 20 to $70 \mathrm{MPa}$ and 28 days to 4 years old [5], [9], [10]. Santhanam [5], Moradi-Marani [11], Carelli [12], Hofmann [13] and Silva [14] studied the behavior of attenuation parameters in cubic concrete specimens and reinforced concrete beams subjected to loading. The results have shown that attenuation parameters are more sensitive than pulse velocity to the presence of damage. Hauwaert [7] analyzed cubic concrete specimens with saw-cut and reported that the maximum amplitude and the energy are more sensitive to the presence of microcracks. Camara [15] analyzed cubic concrete specimens with non-homogeneities and observed that the group velocity and the time instants corresponding to percentages of the energy are more sensitive to the presence of nonhomogeneities. In addition, Aggelis et al. [16] and Souza and Pinto [10] simulated a repair process using epoxy for filling cracks in concrete specimens and reported that the maximum amplitude and the total energy increase, as the epoxy fills the crack.

In concrete structures subjected to fire, the damage detected by the ultrasound method is related to physicochemical changes in the cement paste and the aggregates, as well as their thermal incompatibility [17], [18]. The first effects of the temperature rise occur when concrete is heated around $100{ }^{\circ} \mathrm{C}$. The cement paste starts to lose the free water present in the pores, followed by capillary, adsorbed, and interlayer waters, contributing to the porosity and the calcite increase [17], [19], [20]. In addition, ettringite starts to decompose [20], [21]. Between 105 and $110^{\circ} \mathrm{C}$, chemically bound water from the calcium silicate hydrate (CSH) starts to be released [18], [22]. At $180^{\circ} \mathrm{C}, \mathrm{CSH}$ gel starts to dissociate and, consequently, the cement paste loses its binding property, and its porosity increases [21]. Between 200 and $300{ }^{\circ} \mathrm{C}$, capillary water evaporates completely [19]. Above $300{ }^{\circ} \mathrm{C}$, the siliceous aggregates lose their strength more expressively, resulting in the shrinkage, the appearance of microcracks, and the reduction in the mechanical properties of the concrete [22-24]. At $350^{\circ} \mathrm{C}$, calcium hydroxide starts to decompose into lime and water [18]. From $400{ }^{\circ} \mathrm{C}$, Portlandite crystals start to dehydroxylate, contributing to shrinkage and microcracks in the cement paste [17], [23]. Above $500^{\circ} \mathrm{C}$, most changes in concrete are considered irreversible [22].

Studies that use ultrasonic testing to assess the integrity of heated concrete usually limit their analysis to the ultrasonic pulse velocity (UPV) [4], [25], [26]. However, Yamada et al. [27] stressed the importance of detailed waveform analysis. Therefore, they also evaluated the behavior of the maximum amplitude and the total energy of the ultrasonic signal in concretes heated up to $600{ }^{\circ} \mathrm{C}$. They verified that, in most cases, these parameters decrease as the temperature increases and reported that an accurate evaluation of their sensitivity to temperature changes is required. The authors are not aware of studies that assess the behavior of group velocity, accumulated energy, and time instants corresponding to percentages of the energy in heated concrete.

This work aims to assess the behavior and the sensitivity of the following ultrasonic parameters: pulse and group velocities, maximum amplitude, total energy, accumulated energy, and time instants corresponding to $25 \%, 50 \%$, and $75 \%$ of the energy, in detecting changes due to thermal degradation of the concrete.

\section{MATERIALS AND EXPERIMENTAL PROGRAM}

In this section, the methodologies applied to the casting and curing of concrete specimens, the ultrasonic testing and the calculation of ultrasonic parameters, the compressive strength testing, and the statistical analysis of the data are presented. 


\subsection{Concrete mixture}

A conventional concrete with a C25 strength class was used. It was produced with: Brazilian Portland cement CP IIZ-32, natural fine sand (sand 1), natural medium sand (sand 2), natural siliceous coarse aggregate, and water from the city of Florianópolis/SC main water supply. The particle size distribution and the physical characteristics of the sands and the coarse aggregate are presented in Figure 1 and Table 1, respectively. They were determined according to the Brazilian standard NBR 7211:2009 [28]. The mix proportions and the characteristics of the concrete are presented in Table 2.
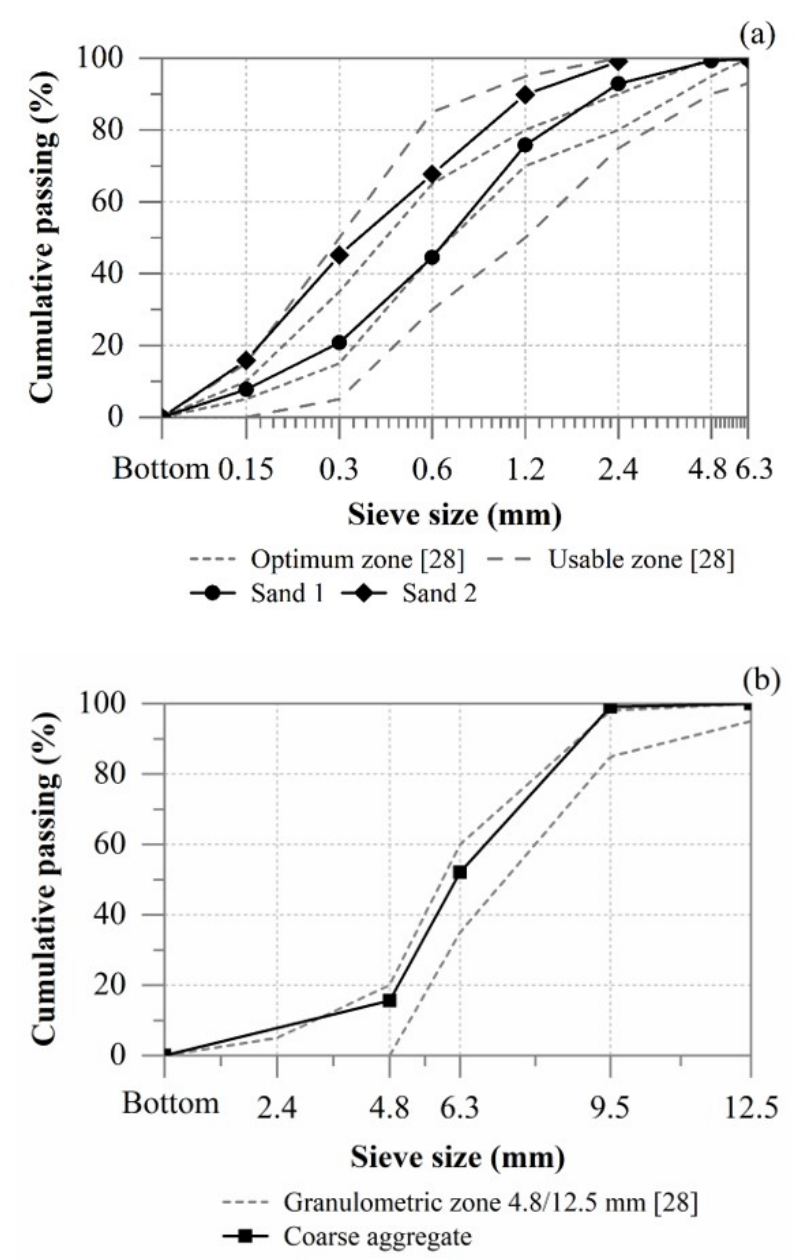

Figure 1. Particle size distribution (a) sands (logarithmic scale); (b) coarse aggregate.

Table 1. Physical characteristics of the sands and the coarse aggregate.

\begin{tabular}{cccc}
\hline & Sand 1 & Sand 2 & Coarse aggregate \\
\hline Fineness modulus & 1.83 & 2.59 & 0.88 \\
\hline Maximum characteristic dimension $(\mathrm{mm})$ & 2.36 & 4.75 & 9.50 \\
\hline Minimum characteristic dimension $(\mathrm{mm})$ & $<0.15$ & $<0.15$ & $<4.80$ \\
\hline Specific mass $\left(\mathrm{g} / \mathrm{cm}^{3}\right)$ & 2.61 & 2.52 & 2.91 \\
\hline
\end{tabular}

Table 2. Concrete mixture and characteristics.

\begin{tabular}{lccccc}
\hline \multirow{2}{*}{ Constituent materials $\left(\mathbf{k g} / \mathbf{m}^{3}\right)$} & Cement & Sand 1 & Sand 2 & Coarse aggregate & Water \\
\cline { 2 - 6 } & 400.16 & 428.17 & 428.17 & 948.38 & 256.41 \\
\hline \multirow{2}{*}{ Characteristics of the concrete } & \multicolumn{2}{c}{ Dry material content $(\mathbf{k g})$} & Mortar content (\%) & Water/cement ratio & Slump test (cm) \\
\cline { 2 - 7 } & \multicolumn{2}{c}{4.51} & 56.99 & 0.64 & 6.50 \\
\hline
\end{tabular}




\subsection{Sample and specimens}

The sample consisted of 47 cylindrical concrete specimens with $100 \mathrm{~mm}$ in diameter and $300 \mathrm{~mm}$ in length, as recommended by RILEM TC 129 MHT [29] for concrete specimens exposed to high temperatures. They were cast and compacted according to the Brazilian standard NBR 5738:2015 [30]. During this process, type K thermocouples were inserted in the geometric centers of 5 specimens to measure their internal temperature throughout the preliminary heating tests.

After 24 hours of casting, the concrete specimens were demolded and stored in a humid chamber for 6 days, as recommended by RILEM TC 129 MHT [29]. Following the curing period, they were exposed to the ambient temperature and humidity of the laboratory environment for another 56 days, to simulate a concrete aging process close to the real and to decrease the interference that late hydration reactions of cement could cause during the concrete heating process [31], [32].

After 28 days of curing, 7 specimens were subjected to compressive strength tests and showed an average compressive strength of $29 \mathrm{MPa}$, with a standard deviation of 1.2 MPa. After 63 days of curing, the concrete specimens were divided into 6 groups and exposed to temperatures between 20 and $500{ }^{\circ} \mathrm{C}$, as specified in Table 3. Once the specimens had cooled, they were subjected to the following tests: mass loss, ultrasound, and compressive strength, as presented in the flow chart illustrated in Figure 2.

Table 3. Number of specimens.

\begin{tabular}{cccc}
\hline \multirow{2}{*}{ Group } & Temperature $\left({ }^{\circ} \mathbf{C}\right)$ & \multicolumn{2}{c}{ Number of specimens } \\
\cline { 3 - 4 } & 20 & Preliminary heating tests & Heating test, ultrasonic test, and compressive strength test \\
\hline$I$ & 100 & - & 7 \\
\hline$I I$ & 200 & 1 & 7 \\
\hline$I I$ & 300 & 1 & 7 \\
\hline$I V$ & 400 & 1 & 7 \\
\hline$V$ & 500 & 1 & 7 \\
\hline$V I$ & & 1 & - \\
\hline
\end{tabular}

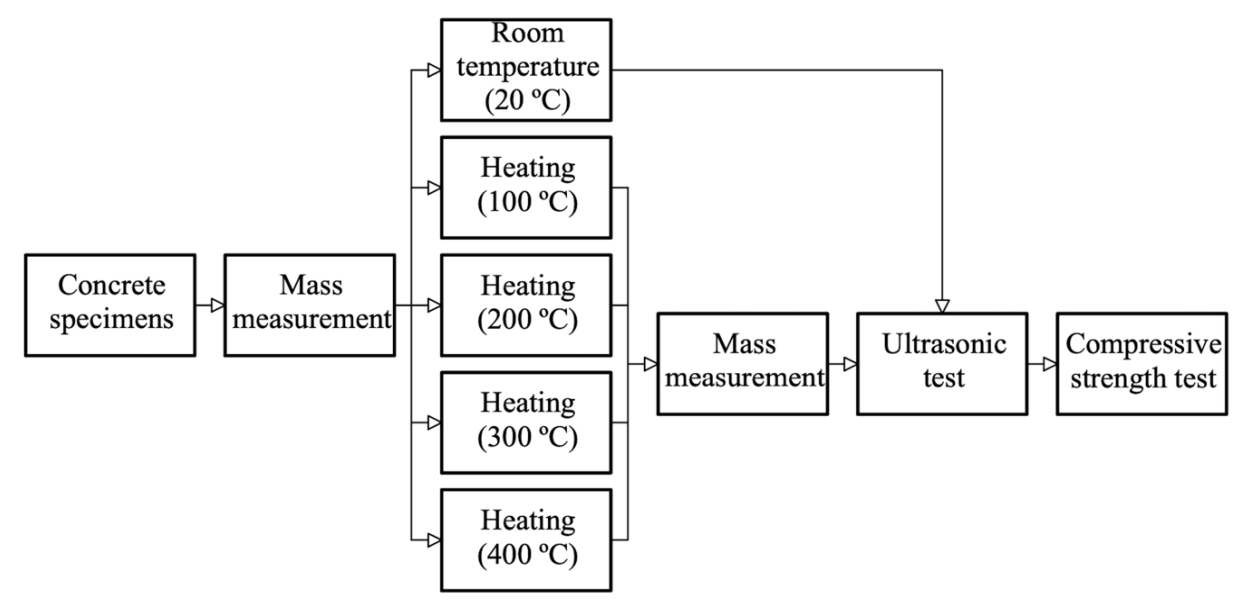

Figure 2. Tests sequence

\subsection{Heating tests}

A muffle furnace with internal dimensions of $460 \mathrm{~mm} \times 610 \mathrm{~mm} \times 590 \mathrm{~mm}, 12 \mathrm{~kW}$ power, and heating capacity up to $1340{ }^{\circ} \mathrm{C}$ was used. Preliminary heating tests were performed using one cylindrical concrete specimen (groups II to VI), with an inserted type $\mathrm{K}$ thermocouple, for each temperature level $\left(100,200,300,400\right.$, and $\left.500{ }^{\circ} \mathrm{C}\right)$. They were heated at a rate of $10{ }^{\circ} \mathrm{C} / \mathrm{min}$ to avoid internal stresses caused by the thermal gradient between the outer and inner parts of the concrete specimens.

During the preliminary heating tests, the internal temperature of the concrete specimens was measured by connecting the thermocouples to a data acquisition system. The obtained data allowed to determine the time required to achieve a homogeneous temperature throughout the specimens. The specimens heated up to $500{ }^{\circ} \mathrm{C}$ suffered an 
explosive spalling precluding the application of the ultrasonic test. Therefore, the following heating tests were performed up to $400^{\circ} \mathrm{C}$.

Groups II to V, composed of 7 concrete specimens each, were heated according to the heating cycles determined based on the preliminary tests, shown in Table 4 . After the thermal treatment, the groups were cooled inside the muffle furnace, until they had reached $150{ }^{\circ} \mathrm{C}$. Subsequently, they were exposed to the ambient temperature and humidity of the laboratory environment for, at least, 24 hours prior to the tests of mass loss, ultrasound, and compressive strength.

Table 4. Heating cycles.

\begin{tabular}{cccc}
\hline Group & Temperature $\left({ }^{\mathbf{C}} \mathbf{C}\right)$ & Time 1 (h-min) & Time 2 (h-min) \\
\hline$I I$ & 100 & $00: 10$ & $03: 50$ \\
\hline$I I$ & 200 & $00: 20$ & $04: 50$ \\
\hline$I V$ & 300 & $00: 30$ & $03: 10$ \\
\hline$V$ & 400 & $00: 40$ & $02: 30$ \\
\hline
\end{tabular}

Time 1: time for the muffle furnace to reach the testing temperature; Time 2: time for the entire specimen to reach the testing temperature.

\subsection{Mass loss measurements}

The mass loss of the specimens was determined by Equation 1. The specimens of Group I were weighed once, while the specimens of groups II to $\mathrm{V}$ were weighed before the heating tests and after the cooling process.

$M L=\left[\left(m_{i}-m_{f}\right) / m_{f}\right] .100$,

where $M L$ is the mass loss (\%), $m_{i}$ is the mass of the concrete specimen before the heating test $(\mathrm{g})$, and $m_{f}$ is the mass of the concrete specimen after the heating test and the cooling process (g).

\subsection{Ultrasonic testing}

The ultrasonic tests were conducted with two piezoelectric transducers, a source, and a receiver of $20 \mathrm{~mm}$ diameter, coupled to the opposite faces of the specimen in a direct transmission arrangement. They excite longitudinal $(\mathrm{P})$ waves with a frequency band of $200 \mathrm{kHz}$. The electric impulses generated by the ultrasonic instrument had a pulse amplitude of $500 \mathrm{~V}$ and a pulse width of $2.5 \mu \mathrm{s}$. The signal response was sampled with a sampling rate of $2 \mathrm{MHz}$ and a recording time window of $5 \mathrm{~ms}$.

Before starting the tests, the specimens of groups I to $\mathrm{V}$ were prepared according to the Brazilian standard NBR $8802: 2019$ [33]. Subsequently, the ultrasonic instrument was calibrated through the coupling of the transducers to the calibration rod, using a coupling gel between the surfaces. Twenty measurements were performed for each specimen, to ensure sufficient data and to reduce the variability in the results. Based on the average of the data signals obtained for each specimen, the following parameters were analyzed: pulse and group velocities, maximum amplitude, total energy, accumulated energy, and time instants corresponding to $25 \%, 50 \%$, and $75 \%$ of the energy (Figure 3 ).

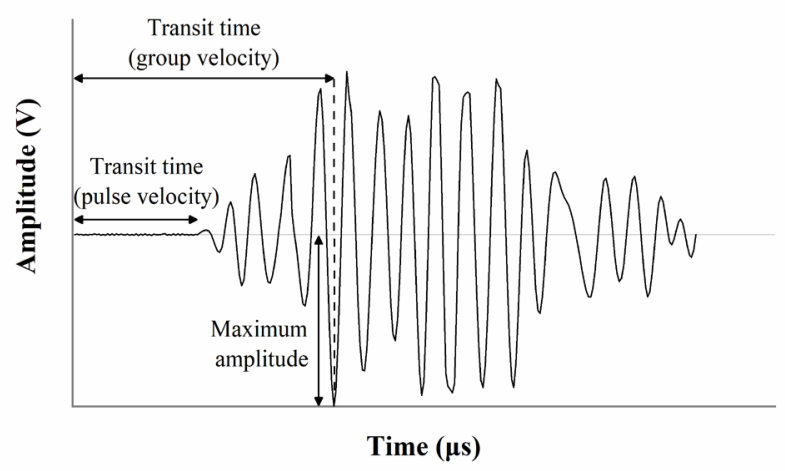

Figure 3. Parameters of a representative ultrasonic wave. 


\subsubsection{Ultrasonic parameters}

The pulse velocity and the maximum amplitude parameters were obtained directly from the ultrasonic signal data, while the group velocity, the total energy, the accumulated energy, and the time instants corresponding to percentages of energy were calculated. The group velocity of the waveforms was calculated using Equation 2, according to Washer et al. [34]. The distance between the transducers, which is the specimen length $(300 \mathrm{~mm})$, and the transit time for the maximum amplitude of the waveform were considered [12], [13].

$V_{g}=L / t_{a m}$,

where $V_{g}$ is the group velocity $(\mathrm{m} / \mathrm{s}), L$ is the distance between the two transducers $(\mathrm{m})$, and $t_{a m}$ is the transit time for the maximum amplitude of the waveform (s).

The total energy of the waveform was calculated by the module of the area under the signal [6], [10], as shown in Equation 3.

$E=\int_{t 0}^{t i}|A(t)| d t$

where $E$ is the total energy (V.ms), $A(t)$ is the amplitude of the signal at time $\mathrm{t}(\mathrm{V}), t$ is the time $(\mathrm{ms}), t_{0}$ is the starting time of the first wave group (ms), and $t_{i}$ is the time corresponding to the end of the first wave group (ms).

The accumulated energy of the waveforms, within the time window of $5 \mathrm{~ms}$, was calculated as the sum of percentages of the energy at intervals of $0.5 \mu$ s [6]. The slope of the curves was calculated by Equation 4 . A range of $0.1 \%$ to $50 \%$ of the energy was considered.

$m=y_{2}-y_{1} / x_{2}-x_{1}$,

where $m$ is the slope of the curve, $y_{2}$ is $50 \%$ of the energy (\%), $y_{1}$ is $0.1 \%$ of the energy (\%), $x_{2}$ is the time corresponding to $50 \%$ of the energy (ms), and $x_{1}$ is the time corresponding to $0.1 \%$ of the energy (ms).

The time instants corresponding to $25 \%, 50 \%$, and $75 \%$ of the energy were obtained by verifying the time that these percentages of energy occurred.

\subsection{Compressive strength measurements}

After the ultrasonic tests, the specimens of groups I to $\mathrm{V}$ were tested with at least 63 days old, according to the Brazilian standard NBR 5739:2018 [35]. The compressive strength of the concrete was calculated by Equation 5.

$\sigma=F_{\max } / A$

where $\sigma$ is the compressive strength of concrete (MPa), $F_{\max }$ is the maximum force applied to the specimen during the test $(\mathrm{N})$, and $A$ is the cross-section area of the specimen $\left(\mathrm{mm}^{2}\right)$.

After obtaining the concrete average compressive strength, the characteristic compressive strength of Group I $\left(20{ }^{\circ} \mathrm{C}\right)$ was calculated according to the Brazilian standard NBR 12655:2015 [36]. Then, the reduction coefficients of the compressive strength were calculated by Equation 6.

$k_{c, \theta}=f_{c, \theta} / f_{c k}$

where $k_{c, \theta}$ is the reduction coefficient of the concrete compressive strength, $f_{c, \theta}$ is the compressive strength (MPa) at temperature $\theta\left({ }^{\circ} \mathrm{C}\right)$, and $f_{c k}$ is the characteristic compressive strength (MPa) at ambient temperature. 


\subsection{Statistical analysis methods}

The influence of temperature on the mass loss, ultrasonic and compressive strength data was statistically analyzed, using a software package. Firstly, the occurrence of outliers was verified, and these data were eliminated [37]. Subsequently, the Kolmogorov-Smirnov normality test was performed, at 5\% significance [38]. For data normality, the analysis of variance test (ANOVA) and Tukey's tests were performed at 5\% probability of error [38]. When the assumption of normality was violated, Kruskal-Wallis and multiple comparisons tests were performed at $5 \%$ probability of error [38].

\section{RESULTS AND DISCUSSIONS}

In this section, the following results are presented and discussed: mass loss, residual compressive strength, ultrasonic pulse velocity (UPV), group velocity, maximum amplitude, total energy, accumulated energy, and time instants corresponding to $25 \%, 50 \%$, and $75 \%$ of the energy.

\subsection{Mass loss}

The mass losses of the concrete specimens due to thermal treatment are illustrated in Figure 4. Groups II to V present an average mass loss of $1 \%, 6 \%, 7 \%$, and $7 \%$, respectively. The Tukey test revealed statistically significant differences among group means, except between the following groups: I and II $\left(20-100{ }^{\circ} \mathrm{C}\right)$, III and IV $\left(200-300{ }^{\circ} \mathrm{C}\right)$, III and V $\left(200-400{ }^{\circ} \mathrm{C}\right)$, IV and V $\left(300-400^{\circ} \mathrm{C}\right)$.

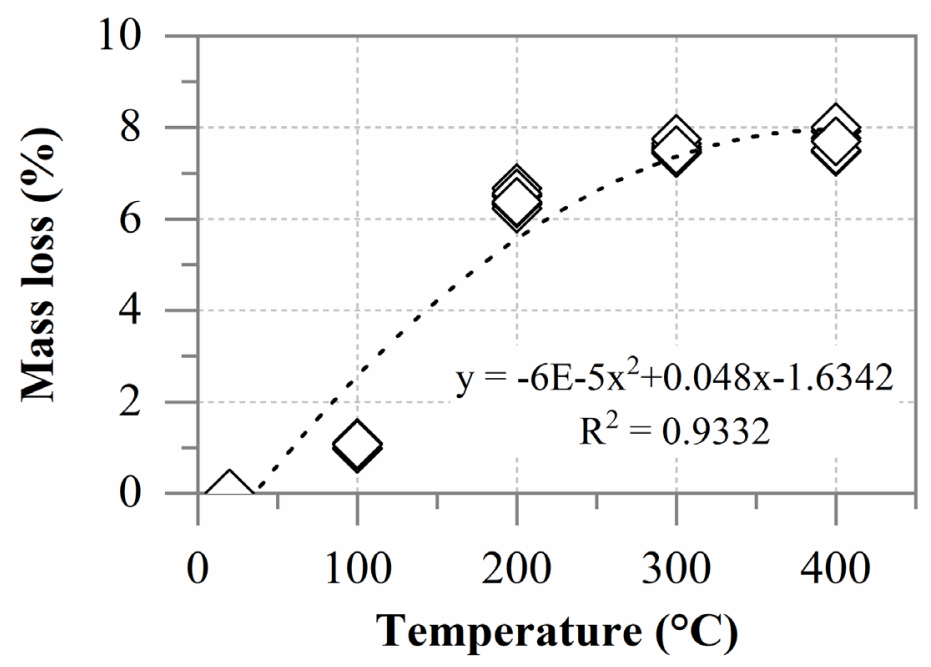

Figure 4. Mass losses of the concrete specimens.

The mass loss increases non-linearly as the temperature increases. Similar results were obtained by Malik [39] and Silva [40], which analyzed concretes with a compressive strength between 40 and $50 \mathrm{MPa}$. The data show that, up to $100{ }^{\circ} \mathrm{C}$, the average mass loss is $1 \%$, since at this temperature the water starts to change its phase from liquid to gaseous [19]. At $200^{\circ} \mathrm{C}$, the average mass loss is more significant, corresponding to $6 \%$, since the physically adsorbed and free waters have already completely evaporated and the chemically bound water starts to be released [18], [19], [39]. Also, the CSH gel starts to dissociate and, consequently, the cement paste porosity increases [21]. At $300{ }^{\circ} \mathrm{C}$, all types of water start to evaporate, and the mass loss is $7 \%$.

Regarding the mass loss measurement, the thermal treatment caused changes in the mass of concrete specimens. The results indicate that the concrete porosity increases, and the chemical compounds were decomposed. These alterations change the compressive strength and the ultrasonic waveform of the concrete. However, a thermogravimetric analysis might be done to verify the chemical changes due to the mass loss.

\subsection{Compressive strength of the concrete}

The compressive strengths of the concrete specimens are illustrated in Figure 5. Groups I to V exhibit an average compressive strength and a coefficient of variation of 35 (15\%), $28(17 \%), 27.5(15 \%), 28(5 \%)$, and $24(6.5 \%) \mathrm{MPa}$, 
respectively. The Tukey test revealed statistically significant differences between the following groups: I and II $\left(20-100{ }^{\circ} \mathrm{C}\right)$, I and III $\left(20-200{ }^{\circ} \mathrm{C}\right)$, I and IV $\left(20-300{ }^{\circ} \mathrm{C}\right)$, I and V $\left(20-400{ }^{\circ} \mathrm{C}\right)$, indicating that the thermal treatment affects the compressive strength of the concrete.

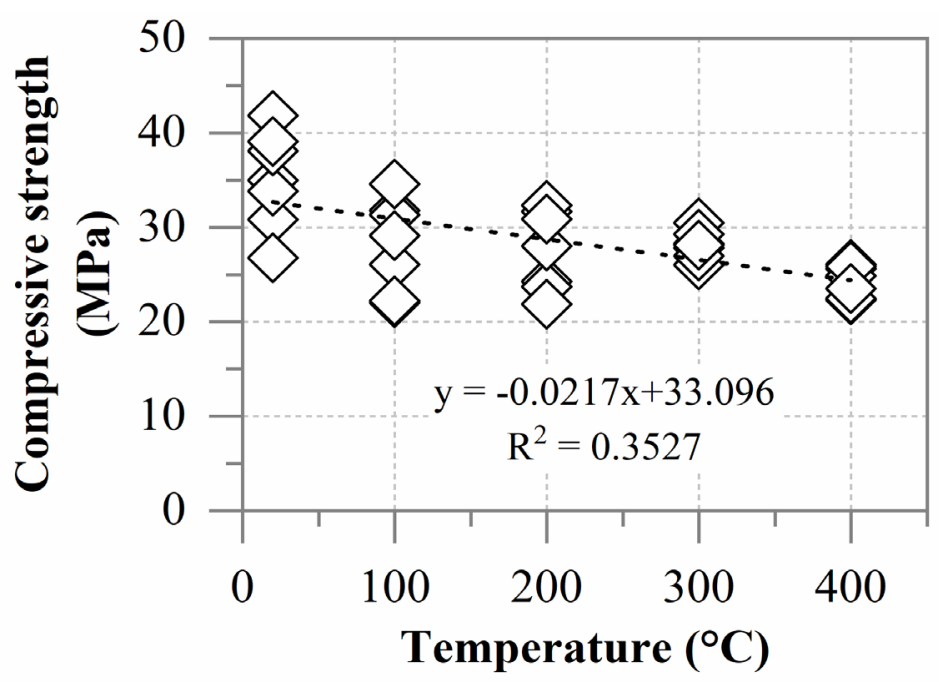

Figure 5. Compressive strength of the concrete specimens.

The data show that the compressive strength decreases as the temperature increases, as observed by Handoo et al. [4], Silva [40], and Ergün et al. [41]. This behavior results from the evaporation of all types of water present in the concrete, the dissociation of the $\mathrm{CSH}$ gel, the dehydroxylation of the Portlandite, the shrinkage of the cement paste, and the thermal incompatibility between the cement paste and the aggregates [17-23]. At $400{ }^{\circ} \mathrm{C}$, the compressive strength reduces $30 \%$, due to the chemical transformations of the cement paste, the breakup of some siliceous aggregates, and the presence of cracks in the transition zone [17], [18].

The reduction coefficients of the compressive strength of thermally treated concrete are shown in Table 5. Between 100 and $300{ }^{\circ} \mathrm{C}$, the reduction coefficients of concrete specimens decrease more expressively, when compared to the reduction coefficients of Brazilian standard NBR 15200:2014 [42]. These differences are probably related to several choices used in this research, especially the rate of heating, the time of exposure to heat, and the cooling process since these factors lead to concrete degradation.

Table 5. The reduction coefficients of the compressive strength of concrete.

\begin{tabular}{cccc}
\hline Group & Temperature $\left({ }^{\circ} \mathbf{C}\right)$ & Reduction coefficients (tests) & Reduction coefficients (ABNT NBR 15200:2012) \\
\hline$I$ & 20 & 1.00 & 1.00 \\
\hline$I I$ & 100 & 0.80 & 1.00 \\
\hline$I I I$ & 200 & 0.79 & 0.95 \\
\hline$I V$ & 300 & 0.80 & 0.85 \\
\hline$V$ & 400 & 0.70 & 0.75 \\
\hline
\end{tabular}

\subsection{Ultrasonic waveforms}

The ultrasonic waveforms on a single concrete specimen of each group (I to V), in a time window of $1.5 \mathrm{~ms}$, are illustrated in Figure 6 . The specimen of group I $\left(20^{\circ} \mathrm{C}\right)$ exhibits higher amplitudes when compared to those of groups II to $\mathrm{V}\left(100,200,300\right.$, and $\left.400^{\circ} \mathrm{C}\right)$. As the temperature increases, the delay increases, and the amplitudes decrease. This behavior is evident from $300^{\circ} \mathrm{C}$. The observed changes on the waveforms are related to the signal attenuation caused by the presence of microcracks and by the increase in the concrete porosity, due to heating [9]. Carelli [12] and Hofmann [13] identified a similar behavior when comparing reinforced concrete beams before and after the presence of cracks. 

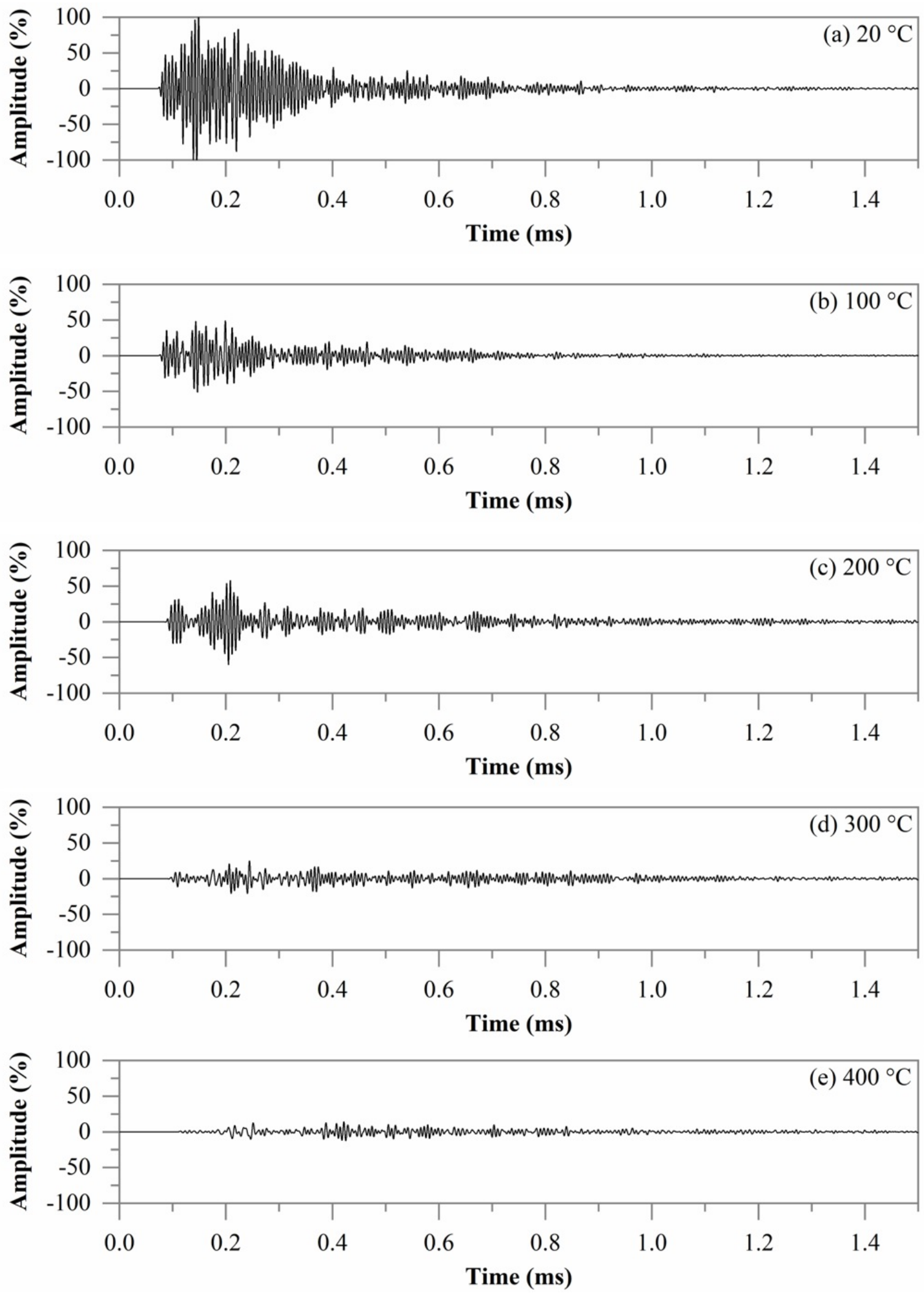

Figure 6. Ultrasonic waveform between $20^{\circ} \mathrm{C}$ and $400{ }^{\circ} \mathrm{C}$. 


\subsection{Average pulse velocities}

The average pulse velocities are illustrated in Figure 7. Groups I to V have an average pulse velocity and a coefficient of variation of $4464(1.1 \%), 4299(1.8 \%), 3835(1.0 \%), 3427(2.8 \%)$, and $2872(2.5 \%) \mathrm{m} / \mathrm{s}$, respectively. The Tukey test revealed statistically significant differences among group means.

The data show that the average pulse velocity decreases linearly as the temperature increases. An average decrease of $4 \%$ $\left(100{ }^{\circ} \mathrm{C}\right), 14 \%\left(200{ }^{\circ} \mathrm{C}\right), 23 \%\left(300{ }^{\circ} \mathrm{C}\right)$, and $36 \%\left(400{ }^{\circ} \mathrm{C}\right)$ is observed. Similar results were obtained by Handoo et al. [4], which analyzed cubic concrete specimens heated for 5 hours. They verified that the average pulse velocity of the concrete group heated at $400^{\circ} \mathrm{C}$ decreased $33 \%$ compared to the average obtained for the unheated group. This is an expected behavior, since high temperatures cause physicochemical changes in the concrete, such as water evaporation, the dehydration of chemical compounds, and the thermal incompatibility between the cement paste and the aggregates [17-23], [43-44]. These cause mass changes, as observed by the mass loss results, also porosity and microcracks, which increase the time to the first detectable disturbance of the wave, consequently, the UPV values decrease [45].

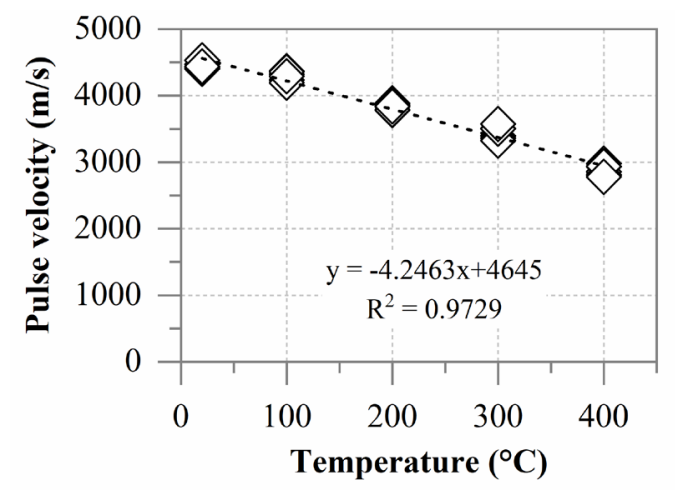

Figure 7. Average pulse velocities.

\subsection{Average group velocities}

The average group velocities are illustrated in Figure 8. After the elimination of outliers [37], groups I to V present an average group velocity and a coefficient of variation of 2320 (19\%), 1854 (8\%), $1444(21 \%), 1826$ (37\%), and 1025 $(38 \%) \mathrm{m} / \mathrm{s}$, respectively. The Tukey test revealed statistically significant differences between the following groups: I and III $\left(20-200{ }^{\circ} \mathrm{C}\right)$, I and V $\left(20-400{ }^{\circ} \mathrm{C}\right)$, II and V $\left(100-400{ }^{\circ} \mathrm{C}\right)$, IV and V $\left(300-400{ }^{\circ} \mathrm{C}\right)$. Therefore, the group velocity can capture the changes undergone by the thermally treated concrete specimens.

The data show that the average group velocity decreases as the temperature increases. However, the average of Group IV $\left(300{ }^{\circ} \mathrm{C}\right)$ is higher than the average obtained for Group III $\left(200{ }^{\circ} \mathrm{C}\right)$. Also, this parameter decreases significantly in the presence of damage when compared to pulse velocity, as evidenced by the reductions of $20 \%\left(100{ }^{\circ} \mathrm{C}\right), 38 \%\left(200{ }^{\circ} \mathrm{C}\right), 21 \%\left(300{ }^{\circ} \mathrm{C}\right)$, and $56 \%\left(400{ }^{\circ} \mathrm{C}\right)$. Similar results were reported by Carelli [12] and Shiotani and Aggelis [6], which analyzed concrete and mortar specimens with artificially induced cracks and cubic mortar specimens containing artificial damage, respectively.

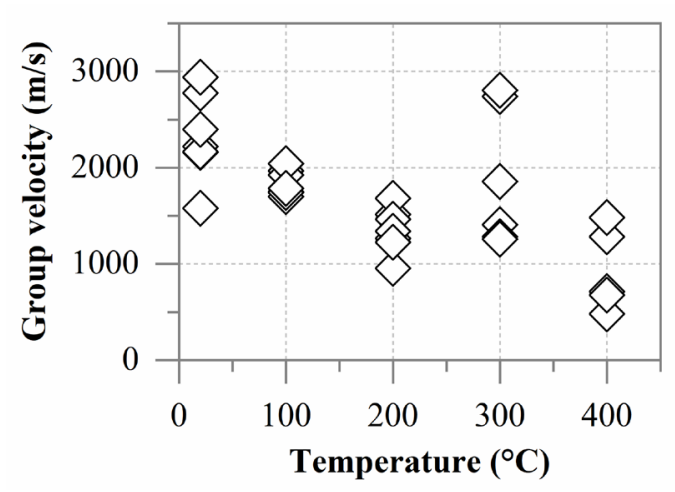

Figure 8. Average group velocities. 
The data also show significant dispersions like those obtained by Camara [15] when analyzing cubic concrete specimens, with and without non-homogeneities. This behavior is probably due to the dependence of the group velocity on the time corresponding to the maximum amplitude of the waveforms, which can vary among concrete specimens due to their heterogeneity [12], [15]. Further studies are required to assess the behavior of group velocity in thermally degraded concrete, evaluating different approaches for its calculation.

\subsection{Average maximum amplitudes}

The average of the maximum amplitudes of the waveforms are illustrated in Figure 9. After the elimination of outliers [37], groups I to V show an average maximum amplitude and a coefficient of variation of $500(0 \%), 273(20 \%), 319(14 \%), 139$ $(14 \%)$, and $80(28 \%) \mathrm{V}$, respectively. The multiple comparisons test revealed statistically significant differences among group means, denoting that the maximum amplitude can capture the changes undergone by concrete specimens heated up to $400{ }^{\circ} \mathrm{C}$.

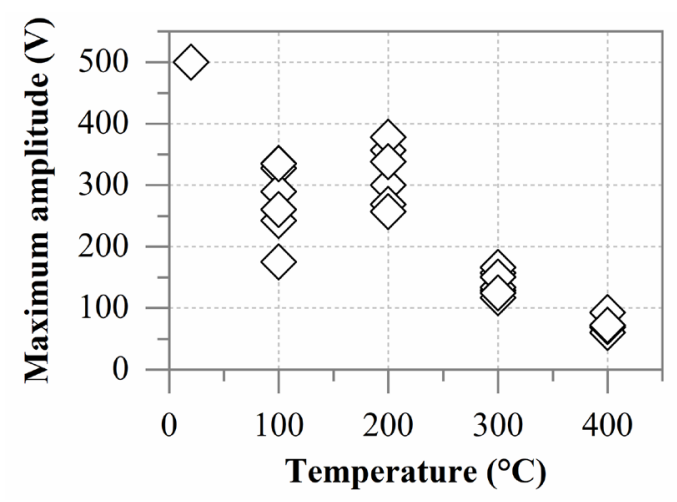

Figure 9. Average maximum amplitudes.

The unheated concrete specimens show waveforms with greater maximum amplitudes. At $100{ }^{\circ} \mathrm{C}$, the average maximum amplitude decreases around $45 \%$ and a relative minimum of $176 \mathrm{~V}$ is verified. This result is probably associated with the greater porosity of this concrete specimen [45]. At $200^{\circ} \mathrm{C}$, the average maximum amplitude reduces only $36 \%$ when compared to the unheated group. At 300 and $400{ }^{\circ} \mathrm{C}$, there is an even more significant decrease in the maximum amplitude due to the intensive attenuation of the signal. Yamada et al. [27] observed similar behavior in concrete specimens with a water/cement ratio of 0.7 heated up to $600{ }^{\circ} \mathrm{C}$.

The heating up to $100{ }^{\circ} \mathrm{C}$ causes the evaporation of free water and the increase of cement paste porosity, which decreases the maximum amplitude of the waveform. Above $100{ }^{\circ} \mathrm{C}$, the loss of free water in the pores, the decomposition of ettringite and the dissociation of $\mathrm{CSH}$ gel, contribute to increasing the concentration of calcite [20-21]. Ngala and Page [46] and Shi et al. [47] states that calcite fills the pores and the voids of cement paste. Therefore, this reaction is probably responsible for the amplitude recovery at $200{ }^{\circ} \mathrm{C}$. Between 300 and $400{ }^{\circ} \mathrm{C}$, the chemically bound and capillary waters have already evaporated, increasing the porosity [19]. Also, the thermal incompatibility between the cement paste and the aggregate increases the number of microcracks in the transition zone [17-18]. Consequently, the maximum amplitude of the waveform continues to decrease.

\subsection{Average total energies}

The average total energies of the waveforms are illustrated in Figure 10. After the elimination of outliers [37], groups I to V show an average total energy and a coefficient of variation of $61(4 \%), 29(4 \%), 42(11 \%), 25(13 \%)$, and $15(6 \%) \mathrm{V} \cdot \mathrm{ms}$, respectively. The Tukey test revealed statistically significant differences among group means, except between groups II and IV $\left(100-300^{\circ} \mathrm{C}\right)$. This demonstrates that the total energy can capture the changes undergone by the thermally treated concrete. 


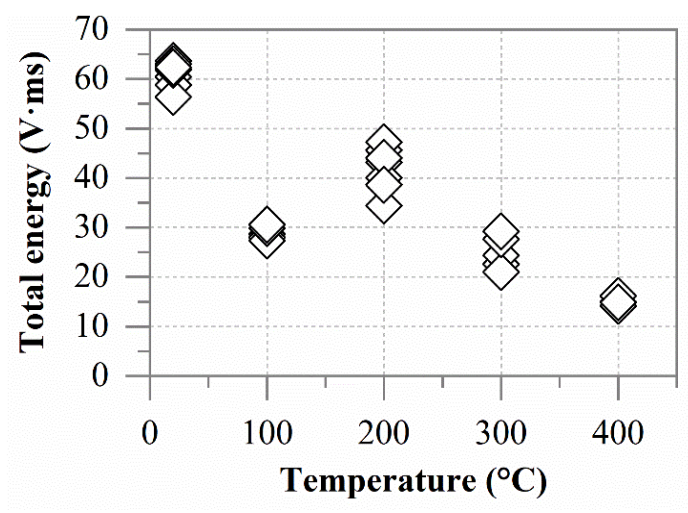

Figure 10. Average total energies.

The data show that the average total energy decreases linearly as the temperature increases, except for Group II $\left(100{ }^{\circ} \mathrm{C}\right)$, which presents a relative minimum. This behavior is like the one presented by the average maximum amplitude, since the energy is related to the amplitudes of the waveform, as observed in Equation 3.

An average decrease of $52 \%\left(100{ }^{\circ} \mathrm{C}\right), 31 \%\left(200{ }^{\circ} \mathrm{C}\right), 59 \%\left(300{ }^{\circ} \mathrm{C}\right)$, and $75 \%\left(400{ }^{\circ} \mathrm{C}\right)$ is observed when compared to the average at $20^{\circ} \mathrm{C}$. Yamada et al. [27] reported similar results when analyzing concrete prisms with water/cement ratios of $0.5,0.6$, and 0.7 heated up to $600{ }^{\circ} \mathrm{C}$. According to Anugonda et al. [8], the loss of energy is due to the combination of scattering and dissipation of the ultrasonic waves, which was observed in Figure 6. In thermally treated concrete, the energy is absorbed by microcracks, and voids developed due to high temperatures [17], [48].

\subsection{Average accumulated energies}

The average accumulated energies of waveforms are illustrated in Figure 11. The transmitted energy reduces gradually as the temperature increases. The average slopes of the curves decrease $3 \%\left(100{ }^{\circ} \mathrm{C}\right), 39 \%\left(200{ }^{\circ} \mathrm{C}\right), 55 \%$ $\left(300{ }^{\circ} \mathrm{C}\right)$, and $65 \%\left(400{ }^{\circ} \mathrm{C}\right)$. The curves of groups I $\left(20^{\circ} \mathrm{C}\right)$ and II $\left(100{ }^{\circ} \mathrm{C}\right)$ show similar behavior. However, the groups heated above $100{ }^{\circ} \mathrm{C}$ show low-sloped curves. Also, at $0.25 \mathrm{~ms}$, Group I reach $50 \%$ of the energy, while groups II to $\mathrm{V}$ reach $48 \%, 34 \%, 23 \%$, and $13 \%$ of the energy, respectively. Therefore, accumulated energy can capture the changes undergone by concrete specimens heated up to $400{ }^{\circ} \mathrm{C}$.

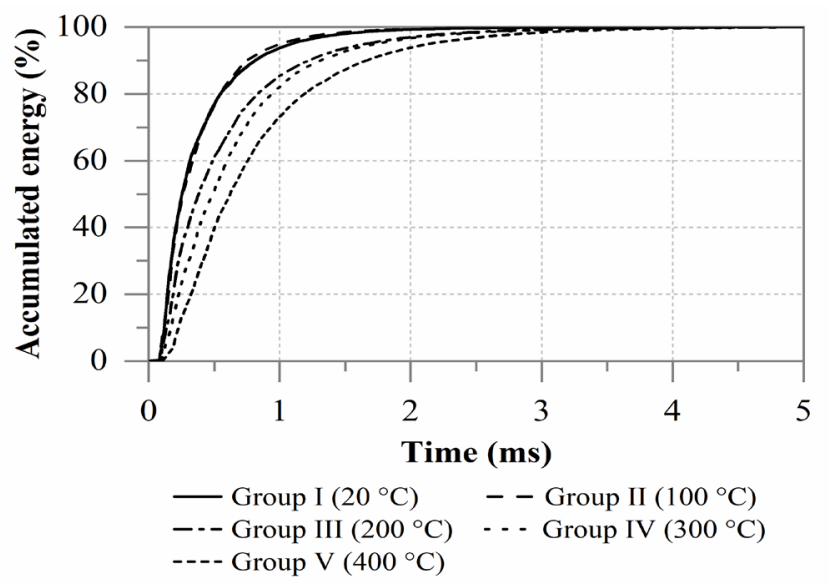

Figure 11. Average accumulated energies of the waveforms.

At the beginning of the time window, groups without or with small damage show greater amplitudes, as observed in Figure 6. As the damage increases, the amplitude of the waveforms reduces since the energy accumulates more gradually over time. Consequently, the slopes of the curves are lower [12]. Similar results were reported by Santhanam [5] and Shiotani 
and Aggelis [6] when analyzing cubic concrete specimens subjected to different load levels and cubic mortar specimens containing artificial damage.

\subsection{Average time instants corresponding to $25 \%, 50 \%$, and $75 \%$ of the energy}

The average time instants corresponding to $25 \%, 50 \%$, and $75 \%$ of the energy waveforms are illustrated in Figure 12 . The time instants corresponding to percentages of the energy increases monotonically as the temperature increases. The Tukey test revealed statistically significant differences among group means, except between groups I and II $\left(20-100^{\circ} \mathrm{C}\right)$. Therefore, the time corresponding to percentages of the energy can capture the changes undergone by the thermally treated concrete specimens.

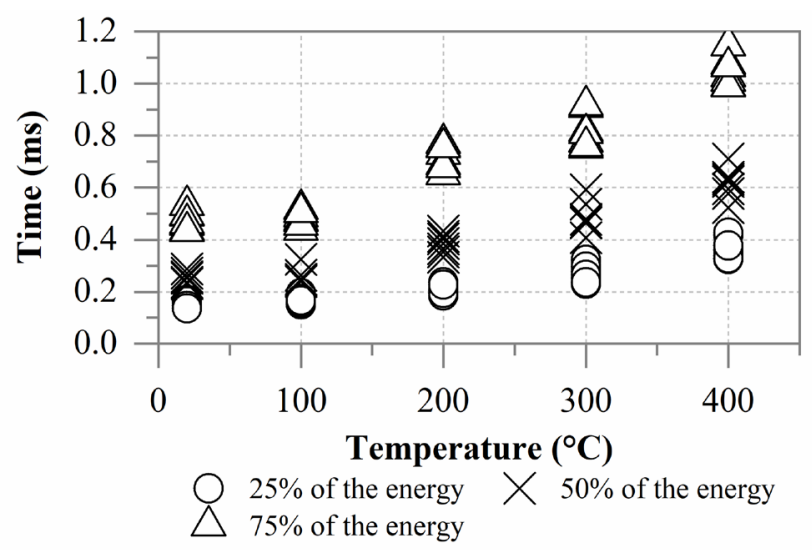

Figure 12. Averages time instants corresponding to percentages of the energy.

The average time instants to reach those energy levels increase significantly above $100{ }^{\circ} \mathrm{C}$. They increase $3 \%$ between 20 and $100{ }^{\circ} \mathrm{C}$ and $45 \%, 79 \%$ and $132 \%$ between the room temperature and 200,300 and $400{ }^{\circ} \mathrm{C}$, respectively. This is caused by signal attenuation, due to the presence of microcracks and voids in the thermally treated concrete specimens [45]. This behavior was also reported by Hofmann [13] and Silva [14] when analyzing reinforced concrete beams before and after the appearance of cracks.

\subsection{Ultrasonic parameters sensitivity}

To evaluate the sensitivity of the ultrasonic parameters to temperature changes, they were normalized from the values obtained at room temperature, as shown in Table 6. All parameters are sensitive to temperatures changes. The pulse and group velocities, the maximum amplitude, the total energy, and the slope of the accumulated energy curve decrease as the temperature increases, while the time instants corresponding to percentages of the energy increase.

Table 6. Normalized ultrasonic parameters.

\begin{tabular}{|c|c|c|c|c|c|c|c|c|c|}
\hline \multirow[b]{2}{*}{ Group } & \multirow[b]{2}{*}{$\begin{array}{c}\text { Temperature } \\
\left({ }^{\circ} \mathrm{C}\right)\end{array}$} & \multicolumn{8}{|c|}{ Ultrasonic parameters } \\
\hline & & $\begin{array}{c}\text { Pulse } \\
\text { velocity }\end{array}$ & $\begin{array}{c}\text { Group } \\
\text { velocity }\end{array}$ & $\begin{array}{l}\text { Maximum } \\
\text { amplitude }\end{array}$ & $\begin{array}{c}\text { Total } \\
\text { energy }\end{array}$ & $\begin{array}{l}\text { Slope of } \\
\text { the curve }\end{array}$ & $T 25 \%$ & $T 50 \%$ & $T 75 \%$ \\
\hline$I$ & 20 & 1.00 & 1.00 & 1.00 & 1.00 & 1.00 & 1.00 & 1.00 & 1.00 \\
\hline II & 100 & 0.96 & 0.80 & 0.55 & 0.48 & 0.97 & 1.05 & 1.04 & 1.01 \\
\hline III & 200 & 0.86 & 0.62 & 0.64 & 0.69 & 0.61 & 1.31 & 1.52 & 1.52 \\
\hline$I V$ & 300 & 0.77 & 0.79 & 0.28 & 0.41 & 0.45 & 1.71 & 1.93 & 1.74 \\
\hline$V$ & 400 & 0.64 & 0.44 & 0.16 & 0.25 & 0.35 & 2.33 & 2.43 & 2.21 \\
\hline
\end{tabular}

T25\%: time instant corresponding to $25 \%$ of the energy; T50\%: time instant corresponding to $50 \%$ of the energy; T75\%: time instant corresponding to $75 \%$ of the energy.

The attenuation parameters change more significantly in the presence of thermal damage when compared to pulse velocity, especially the time instants corresponding to percentages of the energy and the maximum amplitude, since these parameters 
consider the information from the ultrasonic waveform in the entire time window [5], while pulse velocity is measured by the first detectable disturbance of the wave [6]. According to Aggelis and Shiotani [48], even though the wave energy scattering affects the amplitudes, some energy remains scattered in the forward direction. This explains why non-homogeneities, have a limited influence on the pulse velocity, when compared to the attenuation parameters.

The pulse velocity, the slope of the accumulated energy curves and the time instants corresponding to percentages of the energy show a characteristic behavior. The group velocity increases at $300^{\circ} \mathrm{C}$, probably, due to its dependence on the time corresponding to the maximum amplitude, which varies between concrete specimens. The total energy and the maximum amplitude increase at $200{ }^{\circ} \mathrm{C}$, probably due to the presence of calcite [20]. Further research should be undertaken to investigate these topics.

Regarding the ultrasonic parameters, the pulse velocity is the least sensitive parameter, followed by the group velocity, which shows significant dispersions. The slope of the accumulated energy curve, the maximum amplitude and the total energy detects the thermal damage, since the first decreases monotonically as the temperature increases, while the second and the third are very sensitive to thermal damage. However, the time instants corresponding to $25 \%, 50 \%$, and $75 \%$ of the energy are the most sensitive parameters, denoting that they can be the best indicator of thermally damaged concrete. Despite these promising results, further studies are recommended before field applications.

\section{CONCLUSIONS}

In this research, the behavior of pulse and group velocities, maximum amplitude, total energy, accumulated energy, and time instants corresponding to percentages of the energy were analyzed in concrete groups heated at five temperature levels in a range of 20 to $400{ }^{\circ} \mathrm{C}$. The sample consisted of 39 cylindrical concrete specimens measuring $100 \mathrm{~mm}$ in diameter and $300 \mathrm{~mm}$ in length, distributed into five groups, with an average compressive strength of 29 $\mathrm{MPa}$ at room temperature. The results lead to the following conclusions:

- the pulse velocity decreases as the temperature increases, however, it is the least sensitive parameter;

- the group velocity is more sensitive than pulse velocity, but shows significant dispersions;

- the maximum amplitude and the total energy are very sensitive to thermal damage, but further studies must be done to investigate the increase of these parameters at $200^{\circ} \mathrm{C}$;

- the slope of the accumulated energy curve is sensitive to changes in heated concrete since it decreases as the temperature increases;

- the time instants corresponding to $25 \%, 50 \%$, and $75 \%$ of the energy are the most sensitive parameters in detecting changes due to thermal degradation of the concrete.

\section{ACKNOWLEDGEMENTS}

The authors thank the Coordination for the Improvement of Higher Education Personnel (CAPES) for sponsoring this research.

\section{CITATIONS}

[1] International Atomic Energy Agency, Guidebook on non-destructive testing of concrete structures. Vienna: IAEA, 2002.

[2] T. R. Naik, V. M. Malhotra, and J. S. Popovics, Nondestructive testing of concrete, 2nd ed. Florida: CRC, 2004.

[3]

S. A. Kumar and M. Santhanam, "Detection of concrete damage using ultrasonic pulse velocity method," in Proc. National Seminar on Non-Destructive Evaluation, 2006.

[4] S. K. Handoo, S. Agarwal, and S. K. Agarwal, "Physicochemical, mineralogical, and morphological characteristics of concrete exposed to elevated temperatures," Cement Concr. Res., vol. 32, pp. 1009-1018, 2002.

[5] M. Santhanam, "Ultrasonic characterization of damage in concrete," Tech Sci. Press, vol. 3, no. 2, pp. 111-125, 2010.

[6] T. Shiotani and D. G. Aggelis, "Wave propagation in cementitious material containing artificial distributed damage," Mater. Struct., vol. 42, pp. 377-384, 2009.

[7] A. V. Hauwaert, J. F. Thimus, and F. Delannay, "Use of ultrasonics to follow crack growth," Ultrasonics, vol. 36, pp. $209-217,1998$.

[8] P. Anugonda, J. S. Wiehn, and J. A. Turner, "Diffusion of ultrasound in concrete," Ultrasonics, vol. 39, pp. 429-435, 2001.

[9] T. P. Phillipidis and D. G. Aggelis, "Experimental study of wave dispersion and attenuation in concrete," Ultrasonics, vol. 43, pp. 584-595, 2005. 
[10] F. C. Souza and R. C. A. Pinto, "Ultrasonic investigation on the effectiveness of crack repair in concrete," Rev. IBRACON Estrut. Mater., vol. 13, no. 5, 2020.

[11] F. Moradi-Marani, P. Rivard, C. P. Lamarche, and S. A. Kodjo, "Evaluating the damage in reinforced concrete slabs under bending test with the energy of ultrasonic waves," Constr. Build. Mater., vol. 73, pp. 663-673, 2014.

[12] J. M. Carelli, “Análise do comportamento de ondas ultrassônicas em elementos fissurados de concreto e argamassa,” M.S. thesis, Universidade Federal de Santa Catarina, Florianópolis, 2014.

[13] M. A. Hofmann, “Atenuação da energia do sinal ultrassônico na detecção de danos por fissuração no concreto,” M.S. thesis, Universidade Federal de Santa Catarina, Florianópolis, 2015.

[14] P. M. Silva, "Análise da perda de rigidez em vigas de concreto armado devido à fissuração por esforços de flexão utilizando ensaio de ultrassom," M.S. thesis, Universidade Federal de Santa Catarina, Florianópolis, 2017.

[15] R. M. Camara, "Estudo do efeito da variação de pressão de acoplamento no comportamento dos parâmetros ultrassônicos,” M.S. thesis, Universidade Federal de Santa Catarina, Florianópolis, 2017.

[16] D. G. Aggelis, T. Shiotani, and D. Polyzos, "Characterization of surface crack depth and repair evaluation using Rayleigh waves," Cement Concr. Compos., vol. 31, pp. 77-83, 2009.

[17] B. Fernandes, A. M. Gil, F. L. Bolina, and B. F. Tutikian, "Microstructure of concrete subjected to elevated temperatures: Physicochemical changes and analysis techniques," IBRACON Struct. Mater. J., vol. 10, no. 4, pp. 838-863, 2017.

[18] Q. Ma, R. Guo, Z. Zhao, Z. Lin, and K. He, "Mechanical properties of concrete at high temperature—A review," Constr. Build. Mater., vol. 93, pp. 371-383, 2015.

[19] R. C. A. Lima, L. F. Caetano, and L. S. Filho, "Microstructural changes in high density concretes exposed to high temperatures," IBRACON Mater. J., vol. 10, no. 1, pp. 7-14, 2005.

[20] M. Castellote, C. Alonso, C. Andrade, X. Turrillas, and J. Campo, "Composition and microstructural changes of cement pastes upon heating, as studied by neutron diffraction," Cement Concr. Res., vol. 34, pp. 1633-1644, 2004.

[21] M. Malik, S. K. Bhattacharyya, and S. V. Barai, "Thermal and mechanical properties of concrete and its constituents at elevated temperatures: A review," Constr. Build. Mater., vol. 270, pp. 121398, 2021.

[22] O. Arioz, "Effects of elevated temperatures on properties of concrete," Fire Saf. J., vol. 42, no. 8, pp. 516-522, 2007.

[23] B. Georgali and P. E. Tsakiridis, "Microstructure of fire damaged concrete. A case study," Cement Concr. Compos., vol. 27, pp. 255$259,2005$.

[24] G. A. Khoury, "Effect of fire on concrete and concrete structures," Prog. Struct. Eng. Mater., vol. 2, no. 4, 2000.

[25] H. W. Chung, "Ultrasonic testing of concrete after exposure to high temperatures," NDT Int., vol. 18, no. 5, pp. 275-278, 1985.

[26] D. S. Silva, "Propriedades mecânicas residuais após incêndio em concretos usados na construção civil na grande Florianópolis," M.S. thesis, Universidade Federal de Santa Catarina, Florianópolis, 2009.

[27] K. Yamada, H. Tsuchiya, and Y. Kosaka, "Quality evaluation of concrete exposed to high temperature by ultrasonic spectroscopy," $J$. Soc. Mater. Sci., vol. 38, no. 431, pp. 959-965, 1989.

[28] Associação Brasileira de Normas Técnicas, Agregados para concreto - Especificação NBR 7211 2009, 2009.

[29] International Union of Laboratories and Experts in Construction Materials, Systems and structures, test methods for mechanical properties of concrete at high temperatures Rilem TC 129 MHT Part 3-9, 1995.

[30] Associação Brasileira de Normas Técnicas, Moldagem e cura de corpos de prova cilíndricos ou prismáticos de concreto NBR 5738 $2015,2015$.

[31] P. K. Mehta and P. J. M. Monteiro Concreto - estrutura, propriedades e materiais, 2nd ed. São Paulo: Ibracon, 2014.

[32]Laboratoire Central des Ponts et Chaussées, Recommendations for preventing disorders due to Delayed Ettringite Formation. Descartes: Ifsttar, 2009. Accessed: Nov. 06, 2020. [Online]. Available:

https://www.ifsttar.fr/fileadmin/user_upload/editions/ifsttar/guidetechnique/2018-GTI5.A-guidetechnique-Ifsttar.pdf

[33] Associação Brasileira de Normas Técnicas, Concreto endurecido - Determinação da velocidade de propagação de onda ultrassônica NBR 8802 2015, 2019.

[34] G. A. Washer, R. E. Green, and R. B. Pond, "Velocity constants for ultrasonic stress measurement in prestressing tendons," Res. Nondestruct. Eval., vol. 14, pp. 81-94, 2002.

[35] Associação Brasileira de Normas Técnicas, Concreto - Ensaio de compressão de corpos de prova cilindricos NBR $57392018,2018$.

[36] Associação Brasileira de Normas Técnicas, Concreto de cimento Portland - Preparo, controle, recebimento e aceitação Procedimento NBR 12655 2015, 2015.

[37] R. M. Bethea and R. R. Rhinehart, Applied engineering statistics, 1st ed. New York: Marcel Dekker, 1991.

[38] D. C. Montgomery and G. C. Runger, Applied statistics and probability for engineers, 3rd ed. New York: Wiley, 2003. 
[39] M. Malik, S. K. Bhattacharyya, and S. V. Barai, "Microstructural changes in concrete: Postfire scenario," J. Mater. Civ. Eng., vol. 33, no. 2, 2021.

[40] D. S. Silva, "Propriedades mecânicas residuais após incêndio em concretos usados na construção civil na grande Florianópolis,” M.S. thesis, Universidade Federal de Santa Catarina, Florianópolis, 2009.

[41] A. Ergün, G. Kürklü, B. M. Serhat, and M. Y. Mansour, "The effect of cement dosage on mechanical properties of concrete exposed to high temperatures," Fire Saf. J., vol. 55, pp. 160-167, 2013.

[42] Associação Brasileira de Normas Técnicas, Projeto de estruturas de concreto em situação de incêndio NBR 15200 $2012,2012$.

[43] I. Hager, "Behavior of cement concrete at high temperature," Bull. Pol. Acad. Sci., vol. 61, no. 1, 2013.

[44] S. A. Hassan, "Effect of high elevated temperatures on the compressive strength and ultrasonic pulse velocity of high strength concrete," J. Eng. Dev., vol. 11, no. 1, pp. 58-69, 2007.

[45] J. H. Bungey, S. G. Millard, and M. G. Grantham, Testing of concrete in structures, 4th ed. New York: Taylor \& Francis, 2006.

[46] V. T. Ngala and C. L. Page, "Effects of carbonatation on pore structure and diffusional properties of hydrated cement pastes," Cement Concr. Res., vol. 27, no. 7, pp. 995-1007, 1997.

[47] C. Shi, Y. Li, J. Zhang, W. Li, L. Chong, and Z. Xie, "Performance enhancement of recycled concrete aggregate," J. Clean. Prod., vol. 112, pp. 466-472, 2016.

[48] D. G. Aggelis and T. Shiotani, "Effect of inhomogeneity parameters on wave propagation in cementitious material," ACI Mater. J., vol. 105, no. 2, pp. 187-193, 2008.

Author's contributions: ACCV: conceptualization, data curation, formal analysis, methodology, writing; PDM: conceptualization, formal analysis, methodology, writing and supervision; IJP: formal analysis, methodology and writing.

Editors: Lia Pimentel, Guilherme Aris Parsekian. 